\title{
THE RELIGIOUS FACTOR IN NIGERIA'S 2019 PRESIDENTIAL ELECTION
}

\section{Emmanuel O. Ojo}

Emmanuel Ojo is an associate professor of Comparative Politics and Head of the Department of Political Science at the University of Ilorin,

Nigeria

\begin{abstract}
This study analyses the nexus between religion and political behaviour in Nigeria's 2019 presidential election, and the effect on voting behaviour and patterns across the country. The extent of religious cleavages remains substantial and has not diminished over the years. These cleavages follow the Christian/Muslim divide, aside from the denominational differences in Europe and America or the ethnic pluralism in many African states. The impact of indigenous African religions is negligible because there are too many for consideration. This article therefore contributes to the recent resurgence of interest in religion and politics, with the fundamental research question being: does democracy need religion? The paper infers that Nigeria's nascent democracy must promote a secular state, particularly in the face of the deep ethnic and religious differences that are capable of bringing about a democratic reversal to autocracy and absolutism if not well managed.
\end{abstract}

Keywords: cleavages, democratisation, politics and religion, secularism

\section{INTRODUCTION}

On my arrival in the United States, the religious aspect of the country was the first thing that struck my attention.

Alexis de Tocqueville, Democracy in America

This quotation by Tocqueville epitomises the focus of this paper, which is to explore the nexus between politics and religion in Nigeria, particularly political behaviour vis-à-vis voting decisions and patterns in Nigeria's deeply divided society. Tocqueville's wonder embraces admiration as well as surprise. Though religion is not a formal part of the American political system, Tocqueville goes so 
far as to describe it as the first of America's political institutions by virtue of its indirect effects on political life (Tocqueville, cited in Fradkin 2000, p. 87).Similarly, in Nigeria and several other African countries, religion predates the colonial state (Fortes \& Evans-Pritchard 1950; Atanda 2007; Danmole 2012). Nigerians, like many Africans, had been deeply religious long before the advent of colonial rule, and from its inception the Nigerian state has been influenced by religion. Thus, the reality in contemporary Nigerian politics during both military interregnum and civilian rule is that religion and religious matters straddle across the polity. Politics and religion remain Siamese twins conjoined, albeit delicately, and no attempt at separating them has succeeded in developing democracies like Nigeria.

The thrust of this paper is an examination of the social bases of political behaviour (Manza 1957, pp. 38-81). Yet numerous comparative analyses suggest that, in many polities, religious-based cleavages may have been a more important factor for understanding the social bases of voter alignment than the class or ethnic cleavages in a plural and deeply divided country like Nigeria (Manza 1997, p. 39). In view of the aforementioned this article analyses the 2019 presidential election vis-à-vis the role of religion. Previous studies of elections in Nigeria and indeed Africa have paid little attention to the possibly debilitating role of religion in voter education and voter preferences inside the polling units.

The article is in six parts. Following the introduction, the second part discusses the concept of secularism. Part three is an exposition of politics and religion relating to the dilemma in Nigerian politics. Part four reviews the political situation and the influence of religion prior the presidential poll. Part five analyses the results across the six geopolitical zones state-by-state, illustrating the role of religion in influencing voters' behaviour. The conclusion infers that the Nigerian state may need to exercise greater caution to prevent the polity reverting from democracy to autocracy.

\section{THE IDEA OF SECULARISM}

Secularism rejects religious thought and feeling in normal day-to-day interaction in the society (Chaturvedi 2006, p. 280). Individuals may believe in (and practise) their own religion but those beliefs do not form the basis of or part of social behaviour. Thus, religion should remain subjective and should not become objective (ibid.). For Smith (1963, p.4, cited in Davies 1993) a secular state is one that guarantees individual and corporate freedom of religion, deals with the individual as citizen irrespective of his religion, is not constitutionally connected to a particular religion nor does it seek to either promote or interfere with religion. Put differently, a secular state is a state that is established on the assumption that political authority does not require religious legitimation, and to that extent the 
state should not concern itself with the spiritual affairs of its citizens (Davies 1993, p. 81).

Bilton (1987, p. 422) describes the need to separate the state from religion as an expression of the increasing structural differential of society. Such a separation is indeed desirable because a union of both may threaten the liberty of those who have no religion or those whose religious beliefs are in opposition to the state religion (Davies 1993, p. 81).

Historically, the idea of the secular state began in Europe and dominated European political thought in the eleventh and twelfth centuries (Harmon 1964, p. 117). During this time there were disputes between the church and the European states arising from the claims and counter claims by the priests that the church was superior in both temporal and spiritual matters (Thompson 1966, p. 35). The only solution to resolve the dispute came when church and state agreed to demarcate their spheres of interests. By mutual consent, the authority of the church over the citizens was confined to spiritual matters while authority over all temporal matters was vested in the state. From then on religion, which had been the basis of priestly power and prestige, was no longer allowed to dominate the civic life of the state (Davies 1993).

In essence, therefore, the qualified nature of the secular state, as well as the Christian origins of the contemporary Western political system, are not in doubt as the theoretical and prescriptive tilt has been towards separating state and religion (Agbaje 1990, p. 289). The argument has been that:

the cornerstone on which the separation of church and state rests... is the belief that religion cannot be equated with a particular religion without threatening their mutual destruction. Each has its own imperatives.

Thompson 1986, p.13

In the same context, Alasdair Maclntyre (1967, cited in Thompson \& Sharma, 1998, p. 435), secularisation means that in a society in which religion no longer provides a public legitimation for morality, there are only fragments of a conceptual scheme and no rational way of securing moral agreement. In keeping with this structural trend, secularisation was bound to occur because it was defined as a dissociation from religious concerns, with religion losing any overarching character and becoming just another specialised institution, confined mainly to the private sphere. According to Wilson:

Secularization may be defined as that process by which religious thinking, practice and institutions lose social significance and 
become marginal to the operation of the social system ... The structural differentiation of the social system is accompanied by the increasing dependence of society on the articulation of distinct roles, particularly in the economic sphere. Role relationships characterize advance society in which interaction is governed by impersonal criteria: individuals who 'man' these social roles set aside their personal attributes and dispositions and confine their role performances to the relevant skills. It is this impersonality of role-articulated social systems which makes them non- congenial to religion.

Wilson 1988, pp. 953-66

This echoes Max Weber's discussion of rationalisation processes, but it can sometimes become a dualistic view of the individual in which the social roleplaying part of the self is at odds with the irrational particularised individual in modern society. There is no public presence of religion, it is confined to the private sphere which caters to the 'irrational' non-socialised self (Thompson \& Sharma 1998, p. 437).

The 1963 Constitution of Nigeria section 24 sub-section 1, with similar provisions in the 1999 Constitution (as amended) clearly states that Nigeria shall not adopt any state religion:

Everybody shall be entitled to freedom of thought, conscience and religion, including freedom to change his religion or belief, and freedom, either alone or in community with others and in public or private, to manifest and propagate his religion or belief, teaching practice and observance.

This is a declaration of unambiguous neutrality by the state in matters of religion; the basic assumptions that flow from it include but are not limited to the following:

- That the government at all levels shall not be involved in matters of religion;

- That religion will be the private affair of citizens;

- That government funds shall not be used to promote or advance any religion;

- That government at all levels shall be neutral on religious matters;

- That any citizen is free to change his religion as an individual or in a group; 
- That every citizen shall have the right to practise and behave in accordance with his or her religious ethic, including dressing and the use of hijab by female Muslims either at home or in public (Tella 2014, pp. 150-151).

These assumptions form the fulcrum of the idea of secularity which summaries the notion of secularism.

\section{POLITICS AND RELIGION: THE DILEMMA OF NIGERIA'S SECULAR STATE}

Nigeria has well over 400 ethnic groups and is one of the most ethnically diverse countries in the world, with some of the ethnic groups bigger than many states in contemporary Africa (Kirk-Green 1967; Suberu 1998, both cited in Ojo 2009). Nigeria's pluralism is compounded by religious cleavages between Muslims/ Christians in diverse denominations, together with numerous traditional African religions. However, Nigeria's constitution guarantees religious freedom which ensures that both Islam and Christianity are recognised, and African indigenous religions are freely practised.

According to Mazrui, 'long before the religion of the crescent or the religion of the cross arrived on the African continent, Africa was at worship, its sons and daughters were at prayer. Indigenous religions had a concept of divinity which was decentralized' (cited in Asemota 2016, p. 345). Aside from Christianity and Islam, which have been handed down over generations, indigenous African religions have no formal creeds or sacred texts comparable to the Bible and Koran. They find expression, instead, in oral traditions, myths, rituals, festivals, shrines, art and symbols. In the past Westerners sometimes described them as animism, paganism, ancestor worship or simply superstitions, but today scholars acknowledge the existence of sophisticated African traditional religions whose primary role is to provide for human well-being in the present as opposed to offering salvation in a future world.

The World Fact Book 2001 report by the CIA reveals that about 50 percent of Nigeria's population is Muslim, 40 per cent are Christians and 10 percent adhere to indigenous religions (cited in Okolie-Osemene 2010, p. 323). These religious differences have created loopholes in social relations which relate to problems like 'lack of equal opportunities in society, discrimination, exploitation, attacks and lack of protection, communal violence and riots, lack of proper representation in civil services and politics, sexual harassment, poverty and backwardness' usually faced by religious minorities (Swamy 2014, p. 5). In terms of population, it is believed that the numeric strength of a religious group is a political advantage 
over other groups that have fewer adherents. In view of the aforementioned and with specific reference to Nigeria, the study also notes that hundreds of people from both faiths have died in the violence between Christians and Muslims in Nigeria in the past decade (Deji-Folutile 2010, p. 3; Ojo 2010, pp.182-198).

Christians and Muslims dominate the religious sphere of Nigeria's demographic setting, with neither being in a position of numerical superiority for the other to be a weak minority within the Nigerian federation (Agbaje 1990, p. 291). But the snag which has led to the dilemma in Nigeria's supposedly secular state is the existential rivalry between the adherents of the two major religions in public office. The attitude of public office holders vis-à-vis secularity does not really help. Ayoade (1987, p. 184), in a perceptive work, observes that religious bias has proved to be another form of poor power distribution in Nigerian federalism. For instance, in the Second Republic (1979-1983), 'country-wide, Muslims obtained about 70 percent of all executive and board positions'. Nigeria's federal character principle as enshrined in the Constitution provided for ethnic balancing in the convoluting federal arrangement (Ojo 2009) which was formally entrenched in the Constitution in the Second Republic. According to s.14(3) and (4) of 1979 Constitution which has been replicated in the 1999 Constitution (as amended):

(3) the composition of the government of the federation or any of its agencies and the conduct of its affairs shall be carried out in that manner as to reflect the federal character of Nigeria and the need to promote national unity and also to command national loyalty thereby ensuring that there shall be no dominance of persons from a few states or a few ethnic or other sectional groups in that government or in any of its agencies.

(4) the composition of the government of a state, local government council or any of the agencies of such government or council be carried out in such a manner as to recognize the diversity of the peoples within its area of authority and the need to promote a sense of belonging and loyalty among all the peoples of the federation.

The spirit of this principle was defined in the supplementary clause of the 1979 Constitution as the distinctive desire of the peoples of Nigeria to promote national unity, foster national loyalty and give every citizen of Nigeria a sense of belonging' (Ojo 2009, p. 159). Although this was celebrated by some as the 'cornerstone of ethnic justice and fair government in Nigeria', the federal principle has also been denounced by others as a euphemism for federal discrimination 
at best, or geographical apartheid at worst (cited in Olawale 2007, p. 270). The mismanagement of the federal principle resulted in a wide gap between intent and practice. Together with the inability of the principle to accommodate religious differences in the face of religious rivalry between Christians and Muslims, this has done great damage to Nigeria's supposedly secular status, which is not ideal for the stability of the polity and democratic sustenance. Despite its commitment to freedom of religion, Nigeria's federal principle covers only ethnic pluralism without taking cognisance of religious pluralism. This has necessitated informal power-sharing mechanisms that are, at best, observed in the breach. Though government removed ethnic and religious data from the 2006 population census, the two variables continue to play a major role in Nigerian consciousness.

The debilitating impact of this mismanagement of religious sensibility in Nigeria has led to numerous ethno-religious crises in the post-colonial state (Asemota 2016, pp. 338-391; Durotoye 2016, pp. 504-527; Ugwueze 2016, pp. 253-268; Okolie-Osemene 2016, pp. 321-334; Ojo 2010, pp. 182-198; Udofia 2010, pp.124-135).

It is, however, important to emphasise the fact that the Nigerian state has been making conscious efforts during both the military interregnum and civilian rule to balance religious interests. This is by using informal power-sharing mechanisms and sharing executive positions between Christians and Muslims at federal, state and local government levels. The secular nature of the Nigerian state is seen as able to accommodate adherents of both religions while at best ignoring African indigenous religion practitioners (AIR). Table 1 (see below), indicates the performance of Nigeria's post-colonial state vis-à-vis public office and religion.

Table 1: Heads of Government and their Religious Affiliations

\begin{tabular}{|l|l|l|l|l|l|l|l|}
\hline & Name & State & Date & Religion & Name Vice & State & Religion \\
\hline 1. & $\begin{array}{l}\text { Tafawa } \\
\text { Balewa (PM) }\end{array}$ & Bauchi & $1959-1966$ & Islam & $\begin{array}{l}\text { Nnamdi } \\
\text { Azikiwe } \\
\text { (cere- } \\
\text { monial } \\
\text { president) }\end{array}$ & Anambra & Christianity \\
\hline 2. & $\begin{array}{l}\text { Gen. } \\
\text { Aguiyi } \\
\text { Ironsi }\end{array}$ & Anambra & $\begin{array}{l}\text { Jan.-July } \\
1966\end{array}$ & Christianity & - & - & - \\
\hline 3. & $\begin{array}{l}\text { Gen. } \\
\text { Yakubu } \\
\text { Gowon }\end{array}$ & Plateau & $\begin{array}{l}\text { July 1966- } \\
1975\end{array}$ & Christianity & $\begin{array}{l}\text { Chief } \\
\text { Obafemi } \\
\text { Awolowo } \\
\text { (vice chair- } \\
\text { man of } \\
\text { FEC) }\end{array}$ & Ogun & Christianity \\
\hline
\end{tabular}




\begin{tabular}{|c|c|c|c|c|c|c|c|}
\hline 4. & $\begin{array}{l}\text { Gen. } \\
\text { Murtala } \\
\text { Mohammed }\end{array}$ & Kano & $1975-1976$ & Islam & $\begin{array}{l}\text { Gen. } \\
\text { Olusegun } \\
\text { Obasanjo }\end{array}$ & Ogun & Christianity \\
\hline 5. & $\begin{array}{l}\text { Gen. } \\
\text { Olusegun } \\
\text { Obasanjo }\end{array}$ & Ogun & 1976-1979 & Christianity & $\begin{array}{l}\text { Gen. Sheu } \\
\text { Yar'Adua }\end{array}$ & Katsina & Islam \\
\hline 6. & $\begin{array}{l}\text { Sheu } \\
\text { Shagari }\end{array}$ & Sokoto & $1979-1983$ & Islam & $\begin{array}{l}\text { Alex } \\
\text { Ekwueme }\end{array}$ & Anambra & Christianity \\
\hline 7. & $\begin{array}{l}\text { Gen. } \\
\text { Muhammed } \\
\text { Buhari }\end{array}$ & Katsina & 1983-1985 & Islam & $\begin{array}{l}\text { Gen. Tunde } \\
\text { Idiagbon }\end{array}$ & Kwara & Islam \\
\hline 8. & $\begin{array}{l}\text { Gen. } \\
\text { Ibrahim } \\
\text { Babangida }\end{array}$ & Niger & $1985-1993$ & Islam & $\begin{array}{l}\text { Commo- } \\
\text { dore Ebitu } \\
\text { Ukiwe } \\
\text { \& Rear } \\
\text { Admiral } \\
\text { Augustus } \\
\text { Aikhomu }\end{array}$ & Anambra & Christianity \\
\hline 9. & $\begin{array}{l}\text { M.K.O. } \\
\text { Abiola }\end{array}$ & Ogun & $\begin{array}{l}\text { Aborted } 3^{\text {rd }} \\
\text { Republic }\end{array}$ & Islam & $\begin{array}{l}\text { Babagana } \\
\text { Kingibe }\end{array}$ & Adamawa & Islam \\
\hline 10. & $\begin{array}{l}\text { Ernest Shon- } \\
\text { ekan (head } \\
\text { of Interim } \\
\text { Govt.) }\end{array}$ & Ogun & 1993 & Christianity & $\begin{array}{l}\text { Gen. Sanni } \\
\text { Abacha } \\
\text { was head } \\
\text { of the } \\
\text { military }\end{array}$ & Kano & Islam \\
\hline 11. & $\begin{array}{l}\text { Gen. Sanni } \\
\text { Abacha }\end{array}$ & Kano & 1993-1998 & Islam & $\begin{array}{l}\text { Gen. Ola- } \\
\text { dipo Diya }\end{array}$ & Ogun & Christianity \\
\hline 12. & $\begin{array}{l}\text { Gen. } \\
\text { Abdulsalam } \\
\text { Abubakar }\end{array}$ & Niger & 1998-1999 & Islam & $\begin{array}{l}\text { Rear Ad- } \\
\text { miral Mike } \\
\text { Aigbe }\end{array}$ & Edo & Christianity \\
\hline 13. & $\begin{array}{l}\text { Chief- } \\
\text { Olusegun } \\
\text { Obasanjo }\end{array}$ & Ogun & 1999-2007 & Christianity & $\begin{array}{l}\text { Al- } \\
\text { haji Atiku } \\
\text { Abubakar }\end{array}$ & Adamawa & Islam \\
\hline 14. & $\begin{array}{l}\text { Musa } \\
\text { Yar'Adua }\end{array}$ & Katsina & $2007-2010$ & Islam & $\begin{array}{l}\text { Dr. } \\
\text { Goodluck } \\
\text { Jonathan }\end{array}$ & Bayelsa & Christianity \\
\hline 15. & $\begin{array}{l}\text { Dr. } \\
\text { Goodluck } \\
\text { Jonathan }\end{array}$ & Bayelsa & $2010-2015$ & Christianity & $\begin{array}{l}\text { Dr. Nama- } \\
\text { di Sambo }\end{array}$ & Kaduna & Islam \\
\hline 16. & $\begin{array}{l}\text { Muhammed } \\
\text { Buhari }\end{array}$ & Katsina & $\begin{array}{l}2015 \text { till } \\
\text { date }\end{array}$ & Islam & $\begin{array}{l}\text { Prof. (Pas- } \\
\text { tor) Yemi } \\
\text { Osinbajo }\end{array}$ & Ogun & Christianity \\
\hline
\end{tabular}

* Source: Compiled by the Author. 
Table 1 further illustrates that a Muslim president will choose a Christian vice-president, and vice-versa. In most of the federation states Muslim governors also opt for Christian deputies, and vice-versa. An exception was the militarycontrolled transition programme of General Babangida that threw up the late Chief MKO Abiola and Ambassador Babagana Kingibe on a Muslim/Muslim ticket. This was tolerated because Nigerians were tired of long years of military junta. As soon as the information leaked that Bola Ahmed Tinubu - former Governor of Lagos State and national leader of APC - planned to be President Muhammadu Buhari's running mate, Nigerians protested against the idea. With the fear of losing the presidential election in 2015, Buhari had to drop the idea and opted instead for Professor (Pastor) Yemi Osinbajo who was actually nominated by Bola Tinubu as a replacement. The political gimmick was to secure the votes of one of the largest Christian denominations in Nigeria. Similar scenarios played out at state level where, aside from the core north where there is a predominantly Muslim population, governors and their deputies came from the two major religions.

Furthermore, after the elections religion becomes a factor in cabinet composition. Whether explicitly stated or otherwise, the number of Christian and Muslim commissioners in a cabinet is usually an issue. Rather than competence and party loyalty, political leaders are conscious of this fact. Aside from conspicuous public officers, several other appointments are usually made to promote the religious leaning of the executive head responsible for the appointment.

What makes the two contending religions in Nigeria antithetical to democracy is the unfortunate rivalry and stiff competition resulting from the undue manipulation of religion by public office holders (Hassan 2013, pp. 221-247; Igboin 2013). The following examples buttress this point. They were expressed during the constitutional conference organised by the military during the era of General Ibrahim Babangida's lengthy transition. Justice Aniagolu, who chaired the conference, summarised the fears of adherents of both Islam and Christianity. The Christian fears were based on actions and utterances of government officials and some individuals, which tended to give the impression that the country was being progressively Islamised. Some of the grounds for these fears were given as:

- The name of Supreme Military Council was said to have been changed to Armed Forces Ruling Council at the prompting of Muslims who believed that ascribing supremacy to anything other than God/Allah was wrong.

- Nigeria's membership of the Organization of Islamic Conference (OIC) without public debate was intended to favour Muslims. 
- The attempt to secure a loan from the Islamic Bank was also seen as firmly establishing Nigeria in the OIC.

- A Sharia Court of Appeal was established in the Federal Capital Territory even though there were no lower courts to feed it.

- The hospital in Abuja had no mortuary and nowhere in Abuja to buy a coffin. This denied non-Muslims the opportunity of preserving the bodies of their dead before burial at their own chosen time, as Muslims normally bury their dead on the same day of death.

- Some physical structures in Abuja, such as the bus stops, were designed along the lines of Islamic architecture.

- Promulgation of Decree 26 of 1986, which gave Sharia Courts appellate jurisdiction on all civil matters, provided evidence of the progressive Islamisation of the country.

- Government appointments to sensitive establishments are dominated by Muslims.

- Non-establishment of diplomatic relations with Israel was seen as directed against non-Muslims, in favour of Muslims.

- Provocative utterances by some Muslim leaders directed against the non-Muslims, particularly Christians.

- The Federal Government sponsored a delegation to Saudi Arabia for the presentation of the Faisal Award to Sheikh Abubakar Gumi.

- In many states in the country, especially in the north, Christian schools were taken over by government without compensation being paid to the original owners.

On the other hand, the Muslim fears are as follows:

- The present legal system in Nigeria was based on Christian doctrine.

- The continued use of the Gregorian calendar.

- The military officers' salute was a symbol of the cross and Muslim officers were forced to observe the practice.

- Signs at hospitals and other medical institutions denote the Christian symbol of the cross.

- Diplomatic representation in the Vatican (Holy See).

- Observance of Saturdays and Sundays as work-free days (Agbaje 1990, p. 294; Davies 1993; Asemota 2016, pp. 372-373).

These mutual accusations indicate that the Nigerian state is in a dilemma. Except for public office holders who are conscious of the need to keep the state free from religious sentiments and bigotry, the process of democratisation may be a mirage. 
What follows is a discussion of the extent of religiosity on the average Nigerian and how it has influenced the voting behaviour of Nigerians.

\section{PRELUDE TO THE 2019 PRESIDENTIAL POLL}

Ahead of the aborted presidential poll scheduled for 16 February 2019, the Independent National Electoral Commission (INEC) had told Nigerians that the total number of registered voters was eighty-four million (84 004 084). However, the election could not be held until 23 February 2019. INEC later changed the figure of registered voters to eighty-two million (82 344 107). Worse still, while the Commission claimed that there was a total of twenty-nine million (29 364 209) accredited voters it added that there was a total of twenty-seven million accredited voters (27 324583 (Nigerian Tribune 2019, p. 13; see also Ukeh 2018). It was a momentous election in which the registered 84 million voters were to elect a president for another four years. Simultaneously, there was voting for 109 Senate and House of Representatives seats. As expected, the presidential ballot generated keener interest because, more than any other elected official, the president calls the shots in a presidential system of government (The Punch 2019).

Notable issues associated with the 2019 presidential poll include the conflict between Fulani herdsmen and farmers; a comatose economy with mounting foreign and local debts; religious bias on the part of the president towards Muslims; and an ethnic chauvinism ignoring Nigeria's federal character, which was intended to support fairness between different ethnic groups.

The first major concern was the Fulani herdsmen/farmers conflict which claimed thousands of lives across the country but with more intensity in the Middle-Belt zone, that is in predominantly Christian states. Because the returning president happened to be a Fulani Muslim, the opposition Peoples Democratic Party (PDP) cashed in by labelling the All Progressives Congress (APC) candidate and his party one with the Islamisation agenda. Hence, a candidate who could re-order the warped security system was desired. Not only that, whoever won the presidential poll had the unenviable task of uniting the country, jump-starting the comatose economy, and building the decrepit infrastructure deficit estimated at $\$ 3$ trillion dollars. Most of all, Nigeria's existential challenge of redesigning a socially appropriate, politically workable and economically competitive constitutional framework could no longer be delayed (ibid.).

As lofty as the election issues were for assisting the electorate to make reasonable choices, religion became a critical factor in a competitive election with a total of 73 political parties fielding candidates for the election. However, the real electoral battle was between the APC's Muhammadu Buhari and Atiku Abubakar of the PDP. Since 1999 when democracy was inaugurated these two leading parties had alternated power. 
The fundamental question at this juncture is: how does the religious card start playing out? The two leading contestants happened to be Muslims. The two parties envisaged that whatever the margin and no matter how thin, there are more Muslims in the country than Christians. The most reasonable option was the choice of a Muslim candidate to be supported by a Christian running mate. While Muhammadu Buhari opted for Professor (Pastor) Yemi Osinbajo - an ordained minister of the Redeemed Christian Church God (RCCG), one of the leading Christian churches in the country - Atiku Abubakar settled for Mr. Peter Obi, a former governor of Anambra State and a Catholic. The Catholic Church has one of the largest followings in Nigeria. The choice of Christians to deputise was one of the informal power-sharing mechanisms in Nigerian government and politics (Ojo 2000, pp. 44-53).

Bad blood was generated between Christians and Muslims before the 2003 elections, when the antecedents of the APC candidate (Muhammadu Buhari) reportedly instructed Muslims to vote for Muslim candidates only in the 2003 elections (Ayantayo 2009, p. 105). Hence, elections in the country are also periods of religious politics, though this trend does not promote the democratisation process in the country (Okolie-Osemene 2016, p. 329). Nevertheless, less than 24 hours before the presidential election, the Pentecostal Fellowship of Nigeria (PFN) charged its 40-million members nationwide to vote for a candidate whose values aligned with those of the association. The PFN said members should vote for a candidate whose government could eliminate or reduce killings in the country and one who would not use power to control state institutions such as INEC, the Economic and Financial Crimes Commission (EFCC) and the police (The Punch, February 16, 2019 p. 7). The religious body was technically dissuading its members from voting for President Buhari. In the same vein, the Catholic Church too declared that 'Christians have been urged to vote out blood-thirsty politicians who are now moving about canvassing for votes', according to Catholic Vicar Forane, and the Very Rev. Fr. Cletus Chilaka Ugochukwu at the end of January at SS. Peter and Paul Catholic Church, Mbutu Ngwe in Isiala Ngwa South, LGA of Abia State. They counselled Christian faithful not to choose leaders based on sentiment but to elect those who have the fear of God at heart (Sunday Tribune, 2019). These statements were probably targeted at the APC candidate running for federal government, who was perceived to be biased in terms of ethno-religious balancing in a plural society. Earlier in the year members of the Catholic Church and their priests were brutally murdered by Boko Haram insurgents without a single suspect being apprehended. Though Atiku Abubakar of PDP is also a Muslim, he was not seen to be biased towards Islam, nor likely to use his office to promote religious disharmony. For this reason, the Church was deeply involved in trying to influence the electoral decisions of Christians. 
The diocese of Lagos West (Anglican Communion) also restated its commitment to a better Nigeria. Speaking on behalf of the Church in Lagos, the Lord Bishop of the Diocese of Lagos West, the Rt. Rev. (Dr.) James Olusola Odedeji, said that the Church had committed huge resources in support of credible elections, disclosing that the Church deployed 300 well-trained observers across the state, had mobilised 40 buses and drivers and had also drafted church dignities to man a situation room, taking complaints and communicating them to INEC's Lagos office. Odedeji told a national daily that when the Church realised that there was no bond between the leader and the followers, they organised a debate between the 12 candidates contesting the gubernatorial election in Lagos State (The Nation 2019).

The Church did not display just a passive interest in the elections. The umbrella body of Christians across the country - the Christian Association of Nigeria (CAN) - was also critical of the APC candidate because of the way federal government under its watch handled the Fulani/farmers conflicts which had wreaked havoc, mainly in the predominantly Christian communities in the Middle Belt zone of the country. In response, an anonymous columnist Hardball - wrote 'still uncritically carrying partisan sympathies to negate own pristine essence has been CAN's greatest undoing' (The Nation 2019). A number of large Christian organisations joined the fray using social media, most especially WhatsApp messages which circulated among Christians tacitly warning them not to vote for the returning president.

On the other hand, most Muslims were convinced that the pendulum would swing to their side, hinging their optimism on demographics, that is because they have the larger population. The pendulum did indeed swing to their side. Buhari was preferred by them because Atiku was perceived to be a more liberal Muslim. In addition, the chairman of the Muslim community in Oyo State addressed a stakeholders' meeting in Oyo State on 3 March 2019 in preparation for both the governorship and presidential elections, urging them to vote for their own. The convener, Alhaji Kunle Sanni, also visited different zones in the state admonishing Muslim adherents to do the necessary (The Nation, March 4 2019 p. 44). The influence of religion was glaringly obvious in Oyo state election results where the two-term sitting governor of APC lost to PDP. The religious factor was brought about by insensitivity in fielding a Muslim candidate for the governorship as well as the three Muslim senatorial candidates of APC. This infuriated Christians in the state and they mobilised Christians against APC gubernatorial and presidential candidates (Ojo 2019).

All these religious manoeuverings were lost to international observers when they declared the February 23 presidential and National Assembly elections credible and fair, despite the fact that the logistical failure stuck out, like the 
proverbial sore thumb, in many polling precincts across the country (The Nation 2019). The New York Times called the contest between Buhari and Atiku 'a referendum on honesty'. The newspaper had described Atiku as a 'corruptionstained candidate' (Akanni 2019, p. 30). Few observers even considered the role of religion in Nigeria's 2019 presidential and governorship elections. A free and fair poll should reflect voters' choices without their being coerced or cajoled with either money (vote-buying) or an appeal to religious sentiments. That is the thrust of the next section of this paper in analysising the impact of religion on voters' choices nation-wide.

\section{PRESIDENTIAL ELECTION POLL RESULTS AND THE INFLUENCE OF RELIGION}

The 2019 presidential election result is best analysed on zonal basis. Nigeria is divided into six geo-political zones for administrative convenience, with the Federal Capital Territory (FCT) on its own (Ojo 2009, p.163). With the North-East, which comprises six states viz: Adamawa, Bauchi, Borno, Taraba, Yobe and Gombe, the voting patterns in the zone reflected the influence of religion. In Adamawa state, the PDP candidate secured 410266 votes over the APC's candidate of 378078 , which was a slim win by PDP. Religion did not play much role here because it is a predominantly Muslim state. Aside from that, Atiku Abubakar hailed from Adamawa State which boosted his chances; the politics of Adamawa is also unique because more than any other state in the federation, even the 28 governorship candidates were drawn from different religious groups. It is a fairly liberal state with a sizeable number of Christians. Bauchi State in same zone is Muslimdominated but with sizeable number of Christians. APC won with 798428 and the PDP received 209 313. The popularity of Buhari here dwarfed any religious affiliation. Borno State in the zone is also predominantly Muslim. APC won easily with 836496 votes against the PDP candidate's paltry 71 788. Buhari had a cultlike follower from Borno State. He was at a time the Military Governor of Borno State during the military interregnum, and that he was perceived by the electorate as a committed Muslim also helped matters. Taraba State in the same zone has a large population of Christians, so with religious, ethnic and security issues as top consideration, PDP led with 374743 votes as against APC's 324 906. Former Minister of Defence General Theophilous Danjuma, was considered a major force as a Christian who influenced voters in favour of the PDP. Yobe State has large Christian and Muslim constituents, and has cultural affinity with Borno State so the pattern of politics in the two states is often similar. Thus, APC won with a wide margin of 497914 votes against the PDP's 50763 votes in Yobe. In Gombe, a Muslim-dominated state, the APC secured 402961 and the PDP 138484 votes. In 
North-East zone, which has more Muslims than Christians, the APC candidate received 3238773 against the PDP's 1255297 votes (Egburonu 2019, pp. 23-34). In percentile, APC received $71.71 \%$ of the total votes in the zone while the PDP garnered only $27.82 \%$.

North-West zone comprises seven states that are predominantly Muslim, to the extent that Islam has become 'an unofficial state religion' (Bienen 1986, p. 60, also cited in Agbaje 1990, p. 291). It is not surprising therefore that the APC won a landslide victory in the zone with a total of 5954351 against the PDP candidate's 2280465 votes. The state-by-state distribution of votes is equally significant in demonstrating their preference for Buhari, who was perceived as a better symbol of Islam. In Jigawa State APC received 794738 against the PDP's 289 895. Kano State delivered 1464768 votes to the APC while the PDP received 391593 votes. Katsina State, where Buhari hailed from, delivered 1232133 votes against 308 056 for PDP; Kebbi State, 581552 for the APC to 154282 votes to the PDP; while Sokoto State, also known to be hotbed of Islam with its caliphate, gave the APC 449033 and 361604 for PDP. Kaduna State also has large number of Christians but with a majority of Muslims. It delivered 993445 for APC and 649612 for the PDP. Zamfara State, where Sharia law originated, voted APC with 438682 and PDP 125 423. Total vote for this zone was APC 5954351 and 2280465 for PDP. On percentile, APC scored $72.1 \%$ against PDP's $27.61 \%$.

The voting pattern in North-Central axis is different. This zone comprises both states that are predominantly Muslim and those that are dominated by Christians. While APC won in North-West with wide margin, it was a different matter in North-Central where the APC won with 2465599 votes to defeat the PDP's 2023 769. Starting from Benue, a predominantly Christian state, campaigns were based largely on personality. They were, however, also tainted by economics, ethnicity and religion in the light of the herdsmen killings witnessed in the previous two to three years in Benue State. Benue was hardest hit by the crisis, with scores massacred by Fulani herdsmen. In an attempt to win the state, the opposition party PDP highlighted the crisis which cost the state hundreds of causalities. The Buhari-led federal government's lacklustre approach to handling the crisis made matters worse. The state that voted widely for APC in 2015 polls changed its mind and voted PDP, polling 356817 votes to the APC's 347668. Though this was a thin margin they made a statement about defeating APC. In Kaduna State, with sizeable numbers of both Muslims and Christians, the APC had 993445 and PDP 649612 votes. The governor of the state, Mallam el-Rufai, opted for a Muslim/Muslim ticket, disregarding the huge Christian population in Kaduna. He rationalised this on the grounds that even if he were to pick the Pope as running-mate, Christians in the state would not vote for him-a comment that discouraged a number of Christians in that state. Kwara, a predominantly 
Muslim state but with a large Christian population, jettisoned religion and opted for civil revolution - a political movement - with the 'O to ge' (Yoruba for enough is enough) mantra which caught fire like dry leaves in the harmattan, swinging the vote in favour of APC displacing the ruling PDP in Kwara State. In the event, the APC received 308984 votes and PDP 138 184. The electorate spoke with one voice irrespective of their religious leanings, because they wanted change in the political leadership of the state which had been dominated by the Saraki dynasty for over four decades. Niger State is known to be Muslim; there it was a straight fight with APC scoring 612371 to PDP's 218052 votes. Plateau states like Benue in the North Central is predominantly Christian. As expected PDP received 548665 and APC 468555 votes. Kogi State in the same zone has an almost even distribution along Muslim and Christian lines, which is why their result is not as wide. APC scored 285894 votes against PDP's 218 207. Nassarawa State in the same zone voted APC with 289903 and PDP 283 847. The Federal Capital voted PDP with 259997 and 152224 for APC, with Christian civil servants swinging the vote against the APC. Total votes for the zone was APC 2465599 and PDP 2023769 votes. In percentile, APC received 54.5\% and PDP 44.75\%.

Nonetheless, electoral behaviour was tainted by religious sentiments in South-East zone. All five states - Abia, Anambra, Enugu, Ebonyi, and Imo - are predominantly Catholic Christians, and the church had spoken out against the candidature of President Buhari. In Abia State, PDP got 219698 votes against APC's 85 058. In Anambra PDP got 524738 votes to APC's 33298 votes. Enugu State also performed to type with 355553 votes for PDP and 54423 votes for APC. In Imo State, PDP got 334923 to APC's 140 462. In Ebonyi State, APC scored 90726 to PDP's 258573 votes. The total votes scored by the two contending parties differ greatly; PDP got 1693485 votes while APC could only garner 403968 in the whole zone. As the percentile of total votes in the zone, PDP won with $78.18 \%$ and APC 19.1\%.

The South-West zone exhibited quite different electoral behaviour in the 2019 polls. This zone is known for its progressive politics but also consists of a significant mixture of Muslims and Christians as the dominant religious groups (Agbaje 1990, p. 291. Though APC won the zone it was not an easy ride. In Ekiti State APC got 219231 votes to PDP's 154 032. Lagos was more difficult, and the APC scored 580825 to PDP's 448015 votes. This result was considered too close in a state that claimed to be the unofficial headquarters of APC. The state had been governed since 1999 by the progressives, but the large population of predominantly Christian Ibo traders boosted the chances of PDP as they voted in line with the voting pattern in their respective home states. Ogun State delivered 281762 votes to APC because of sizeable number of Muslims there, and gave 194655 to PDP. Ondo State with a large population of Christians (despite a sitting APC governor) voted en masse for PDP with 275901 and 241769 votes for APC. 
Osun State was also not easy as PDP scored 337377 to APC's 347 634. There are more Muslims than Christians in Osun. In Oyo State, the religious card was visibly played along with other factors. Surprisingly, PDP won the state with 366640 votes to APC's 365229 despite the fact that APC went to the polls with a two-term sitting governor. Most Christians in Oyo State were aggrieved and jettisoned the APC candidate, which was a shock to the ruling party. The total votes in the South-West which bailed out the APC were 2036 450, with 1776620 votes for PDP. In percentile of total votes in the zone, APC got $51.94 \%$ and PDP $45.31 \%$.

The South-South zone consists of six states that are all significantly Christian; as expected, PDP won there with 2233232 votes against APC's 1051396 votes. A consideration of vote distribution across the zone revealed that in Bayelsa State APC had 118821 votes to PDP's 197933. Akwa Ibom State delivered 395832 to PDP and 175429 votes to APC. Cross River state voted PDP with 295737 and 117302 votes for APC. Delta state also voted PDP with 594068 and 221292 for APC. Edo state returned 275691 for PDP and 267842 for APC. Rivers state voted 473971 for PDP and 150710 for APC. The total vote in the zone was 2233131 votes for PDP and 1051396 votes for APC. In percentile, PDP received 67.59\% to APC's 31.82\%.

\section{CONCLUSION}

The foregoing results clearly indicate that religion was a visible factor in voters' choices in the 2019 presidential polls across the country. While this was no surprise in the core north, south-east and south-south, the south-west was for the first time greatly influenced by religion rather than the progressive ideology that states in the zone are known for in their voting decisions. Christians in the zone were influenced by the opposition PDP campaigns that painted the ruling party, the APC, in a bad light as having an Islamic agenda. This was lent credence to by the response of APC-led federal government that had been feeble in its response to the conflict between herdsmen and farmers in Christian-dominated states. In addition, the Boko Haram insurgents compounded the situation by attacking churches while the state appeared incapable of bringing the miscreants to book.

Buhari's presidency tilted in favour of the Muslim north and as a result most appointments made before and after the 2019 polls reflected an asymmetric relationship skewed in favour of the Muslim north. This warranted a stinging editorial in the flagship of Nigeria's print media, The Guardian (10 September 2019) entitled 'A federation nurtured by partiality'. The paper commented: 'as some observers have noted, players at the centre forget easily that our country is a federal secular state and have carried on haughtily without caring a hoot about the foundational bricks that make for an enduring union'. Nigeria's federal 
character covers only ethnic pluralism without cognisance of religious pluralism. Yet these two variables continue to play a major role in Nigerian consciousness.

The state needs to display better attributes of secularity in all ramifications in order to downplay religious influences on Nigeria's electoral behaviour. The Election Management Body (EMB) for its part also needs to educate the electorate in making rational choices devoid of religious or ethnic colourations that are inappropriate in developed democracies.

Finally, the Nigerian state needs to improve the education sector. The more educated the citizenry, the better they are able to make informed electoral decisions in the polity. Manipulation of religion is antithetical to Nigeria's democratisation, and the country's nascent democracy can be nurtured only when voters are neither coerced nor manipulated by extraneous factors like religion.

\section{----- REFERENCES -----}

Agbaje, A 1990, 'Travails of the Secular State: Religion, Politics and the Outlook on Nigeria's Third Republic', The Journal of Commonwealth and Comparative Politics, vol. XXVIII, no. 3.

Akanni, B 2019, '2019 Polls and Consolidation of Democracy', The Nation, Lagos, March 8, p. 30.

Albert, IO 2007, 'The Yoruba and the National Question', in EE Osaghae \& E Onwudiwe (eds), The Management of National Question in Nigeria, John Archers, Ibadan.

Asemota, S 2016, 'Religious Divide as the Greatest Challenge to Good and Democratic Governance in Nigeria: A case for Democracy, Religious Freedom and Reconciliation', in C. Dallas \& J. Dakas (eds.), Challenges of Good and Democratic Governance in Nigeria (Essays in honour of Prof. Ben Nwabueze), John Archers, Ibadan, Nigeria.

Atanda, JA 2007, 'Religious and Social Life up to c.1910', in GO Oguntomisin (ed), A Comprehensive History of the Yoruba People up to 1800, John Archers, Ibadan, Nigeria.

Ayantayo, JK 2009, 'Religious Factors in the Nigerian Public Sphere: Burden and Prospects', Africa Development, vol. XXXIV, nos. 3 \& 4.

Ayoade, JAA 1987, 'Ethnic Management in the 1979 Nigerian Constitution', Canadian Review of Studies in Nationalism, vol. xiv, no. 1.

Bienen, H 1986, 'Religion, Legitimacy and conflict in Nigeria', The Annals of the American Academy of Political and Social Science, vol. 483.

Bilton, T 1987, Introductory Sociology, Macmillan, London.

Danmole, HO 2012, 'Religion, Politics and the Economy in Nineteenth Century 
Ilorin: Some Reflections', $1^{\text {st }}$ in the Lecture Series of the Centre for Ilorin Studies, (CILS), University of Ilorin, Ilorin, Nigeria (held on $12^{\text {th }}$ December), Unilorin Press, Ilorin, Nigeria.

Davies, AE 1993, 'Secularity and State Practices in Nigeria' in HO Danmole, AE Davies \& IO Taiwo (eds), Contemporary Issues in Nigerian Affairs, Sunad, Ibadan, Nigeria.

Deji-Folutile, O 2010, 'Faith in God: Africans among World's most religious people', in The Punch, April 23.

Durotoye, A 2016, 'The State and the Management of Religious Violence in Nigeria: The case of Boko Haram', in J Shola Omotola \& M Alumona (eds), The State in Contemporary Nigeria: Issues, Perspective and Challenges, John Archers, Ibadan, Nigeria.

Egburonu, S 2019, '2019 Polls Aftermath: State of the States', The Nation on Sunday, Lagos, 17 March, pp. 23-34.

Fortes, M \& Evans-Pritchard, EE 1950, African Political Systems, Oxford University Press, London.

Fradkin, H 2000, 'Does Democracy Need Religion?' Journal of Democracy, vol. 11, no. 1 (January).

Harmon, MJ 1964, Political Thought, McGraw-Hill, New York.

Hassan, EL 2013, 'The Manipulation of Religion in Nigeria: Implications for Democratic Governance', in B Sofela, VO Edo and RO Olaniyi (eds), Nigeria at 50: Politics, Society and Development, John Archers, Ibadan, Nigeria.

Igboin, BO 2013, 'From Religion conflict to Religious Nationalism: The Nigerian Experience', in B Sofela, VO. Edo \& RO Olaniyi (eds), Nigeria at 50: Politics, Society and Development, John Archers, Ibadan, Nigeria.

Manza, J 1997, 'The Religious Factor in U.S. Presidential Elections, 1960-1992', American Journal of Sociology, vol. 103, no. 1 (July).

Mazrui, AA 1986, The Africans: A Triple Heritage, BBC \& Little Brown, London. Nigerian Tribune 2019 ,March 6, p. 13.

NwarayanaSwami, A 2014, 'International Perspective to Protect the Human Rights of Religious Minorities: A critical Study', IOSR Journal of Humanities and Social Sciences, (IOSR-JHSS), vol. 19, Issue 12.

Ojo, EO 2000, 'Nigeria's New Modes of Power Sharing: A Prognosis', African Notes, vol. XXIV, nos. 1 \& 2.

Ojo, EO 2009, Mechanisms of National Integration in a Multi-Ethnic Federal State: The Nigerian Experience, John Archers, Ibadan, Nigeria.

Ojo, EO 2010, 'A survey of Ethno-Religious Crisis and its implications for Nigeria's Nascent Democracy', Journal of Sustainable Development in Africa, vol. XII, no. 2.

Ojo, G 2019, ‘Does Democracy need religion'? Sunday Punch, April 28, p. 17. 
Okolie-Osemene, J 2016, 'The State and Religion in Nigeria' in J Shola Omotola \& M Alumona (eds), The State in Contemporary Nigeria: Issues, Perspectives and Challenges (Essays in Honour of Prof. Ben O. Nwabueze), John Archers, Ibadan. Sunday Tribune 2019, February 24, p. 36.

Tella, L 2014, 'Media and Religious Crisis in Nigeria: Any Consonance?', Centrepoint Journal (Humanities Edition), vol. 17, no. 2 (Dec).

The Guardian 2019, 'A federation nurtured by partiality' (editorial comment), 10 September.

The Nation 2019, 'Final Push (editorial comment)', 8 March, p. 17.

The Nation 2019, March 11, p. 48.

The Nation 2019, March 16, p. 8.

The Punch 2019, 'Difficult days ahead' (editorial comment), February 15, p.18.

The Punch 2019, 'Pentecostal Fellowship of Nigeria's Benchmark for an electable Presidential / gubernatorial Candidates for Good Governance, 16 February, p. 7.

Thompson, K \& Sharma, A 1981, 'Secularization, moral regulation and the Mass Media', British Journal of Sociology, vol. 48, no. 3 (September).

Thompson, KW 1986, 'Religion and Politics in the United States: An Overview', The Annals of the American Academy of Political Science, vol. 483, no. 13.

Thompson, WD 1966, 'Martin Luther and the Two Kingdoms', in D Thompson (ed), Political Ideas, Penguin Books, London.

Udofia, D 2010, 'The Role of Religion in Anti-Corruption War and Management of National Security in Nigeria', in IO Albert \& ON Olarinde (eds), Trends and Tensions in Managing Conflicts, a publication of Society for Peace Studies and Practice, John Archers, Ibadan, Nigeria.

Ugwueze, MI 2016, 'Ethno-Religious Conflicts and Nigeria's National Security', in J Shola Omotola \& M Alumona (eds), The State in Contemporary Nigeria: Issues, Perspective and Challenges, John Archers, Ibadan.

Ukeh, O 2018, 'Voters' Registration and 2019 Polls', Daily Sun, September 7.

Wilson, BR 1988, 'Secularization: Religion in the Modern World', in S Sutherland (ed.), The World's Religions, Routledge, London. 